E-Article

\title{
When Resistance Is Useless: Policing and the Evolution of Reproductive Acquiescence in Insect Societies
}

\author{
Tom Wenseleers, ${ }^{1, *}$ Adam G. Hart, ${ }^{2, \dagger}$ and Francis L. W. Ratnieks ${ }^{2, \ddagger}$
}

1. Laboratory of Entomology, Zoological Institute, University of Leuven, Naamsestraat 59, B-3000 Leuven, Belgium;

2. Laboratory of Apiculture and Social Insects, Department of Animal and Plant Sciences, University of Sheffield, Sheffield S10 2TN, United Kingdom

Submitted March 18, 2004; Accepted August 12, 2004; Electronically published November 9, 2004

Online enhancements: Mathematica notebook and code.

\begin{abstract}
In social groups composed of kin, inclusive fitness benefits can favor greater cooperation. Alternatively, cooperation can be enforced through the policing of less cooperative individuals. Here, we show that the effect of policing can be twofold: not only can it directly suppress individual selfishness, it can also entirely remove the incentive for individuals to act selfishly in the first place. We term such individual restraint in response to socially imposed policing "acquiescence" and illustrate the concept using examples drawn from the social Hymenoptera (the ants, bees, and wasps). Inclusive fitness models confirm that when a policing system is in place, individuals should be less tempted to act selfishly. This is shown to have important consequences for the resolution of conflict within their societies. For example, it can explain why in many species very few workers attempt to reproduce and why immature females usually do not attempt to develop as queens rather than workers. Although our analyses are primarily focused on the social insects, our conclusions are likely to be general and to apply to other societies as well.
\end{abstract}

Keywords: social policing, altruism, acquiescence, social insects, worker reproduction, caste conflict.

Nonclonal individuals within social groups frequently have dissimilar reproductive interests, leading to conflict (Rat-

\footnotetext{
* Present address: Wissenschaftskolleg zu Berlin, Institute for Advanced Study, Wallotstrasse 19, 14193 Berlin, Germany; e-mail: tom.wenseleers@bio .kuleuven.ac.be.

† E-mail: a.hart@sheffield.ac.uk.

‡ E-mail: f.ratnieks@sheffield.ac.uk.
}

Am. Nat. 2004. Vol. 164, pp. E154-E167. (C) 2004 by The University of Chicago. 0003-0147/2004/16406-40349\$15.00. All rights reserved. nieks and Reeve 1992; Hamilton 1995; Frank 1998; Keller 1999). Conflicts of interest can arise at all levels of social organization, from intragenomic and intercell lineage conflicts within organisms (Hurst et al. 1996; Michod 1999; Pomiankowski 1999) to parent-offspring and interindividual conflicts in families and societies (Trivers 1974; Trivers and Hare 1976; Hamilton 1995; Queller and Strassmann 1998). In social groups, where all individuals are affected to a greater or lesser extent by the behavior of others, conflict is usually detrimental because individuals who serve their own selfish interests reduce group productivity (Hardin 1968; Frank 1995; Heckathorn 1996). However, conflict-induced social collapse is not inevitable because conflicts are often absent or else efficiently resolved (Ratnieks and Reeve 1992).

One situation where conflicts are reduced occurs in groups composed of kin. Greater genetic relatedness between group members increases their similarity of interests, thereby reducing the potential for conflict ("kin selection"; Hamilton 1964, 1995; Maynard Smith 1964; Frank 1998). Social policing, whereby group members mutually suppress each other's selfish tendencies, is another important mechanism that can resolve conflict (Ratnieks 1988; Frank 1995, 1996, 2003). Policing is usually envisaged as some coercive behavior that directly represses individual selfishness (Leigh 1991; Frank 1995, 2003), for example, individuals forcefully preventing the overuse of common resources (Hardin 1968; Leigh 1991; Frank 1995; Ostrom 1999; Ostrom et al. 1999). Additionally, policing can also describe situations where selfish individuals are prevented from being successful. For example, in insect societies, workers often eat or "police" eggs laid by other workers (fig. 1; Ratnieks 1988; Ratnieks and Visscher 1989). Egg eating does not prevent selfish workers from laying more eggs, but it does prevent them from successfully reproducing, thereby maintaining the reproductive monopoly of the queen (Ratnieks 1988; Ratnieks and Visscher 1989).

The above examples emphasize the direct influence of policing. However, policing could also play an additional and important role in resolving conflicts by indirectly mak- 

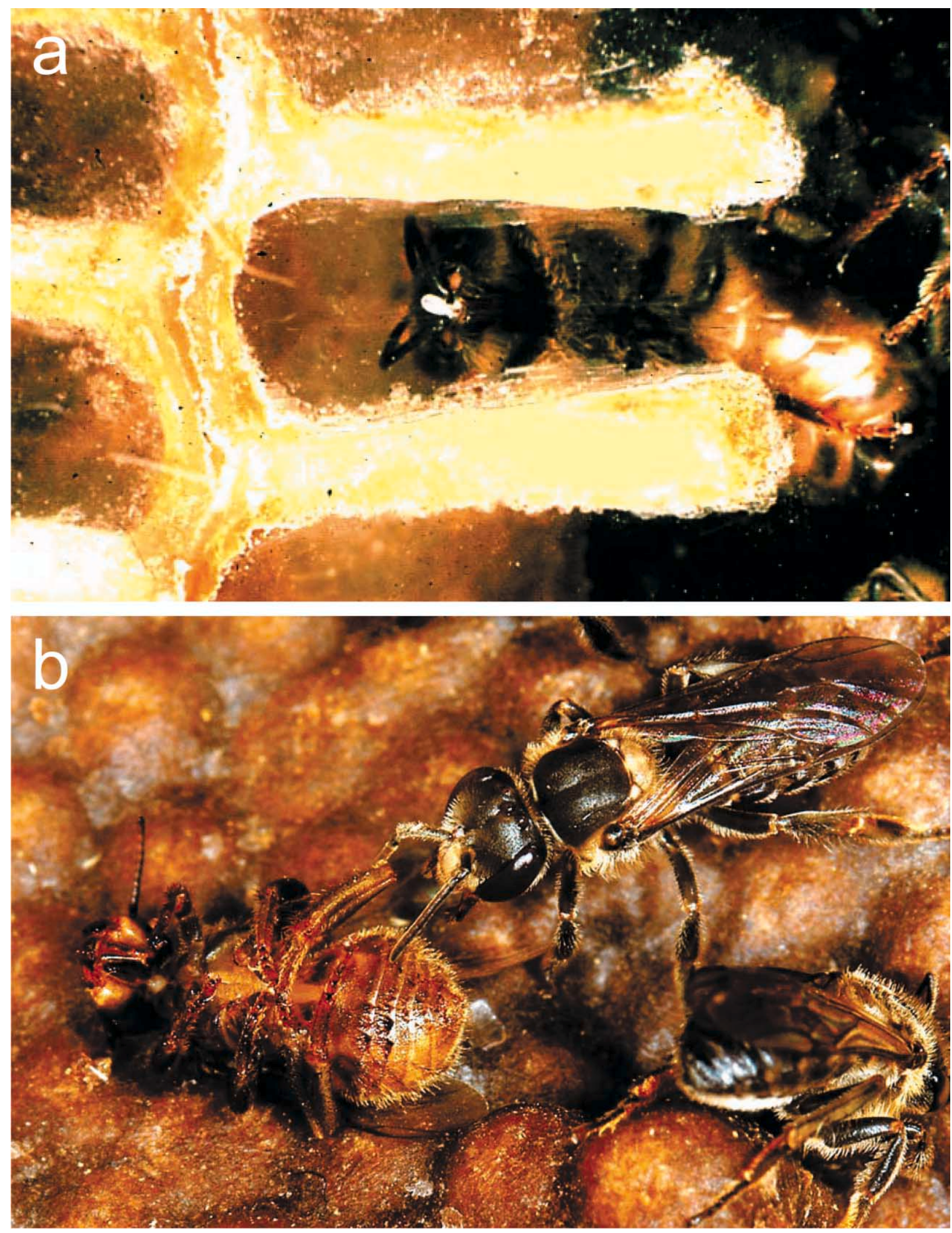

Figure 1: Two forms of social policing in the social Hymenoptera. a, Policing of worker-laid eggs in the honeybee Apis mellifera (Ratnieks and Visscher 1989). b. Execution of a dwarf queen (left) that developed in a worker cell in the stingless bee Schwarziana quadripunctata (Ribeiro and Alves 2001; Wenseleers et al. 2003, 2004b). See text for explanations. Photos by F. L. W. Ratnieks $(a)$ and T. Wenseleers $(b)$. 
ing it unprofitable for individuals to act selfishly. For example, if eggs laid by workers are eaten, then this may select against workers activating their ovaries in the first place. We name this "acquiescence," that is, a situation in which individuals are selected to conform to social norms and regulations that are enforced against transgressors. Although the possibility that policing can indirectly reduce selfishness and favor greater cooperation has been alluded to several times (e.g., Ratnieks 1988; Visscher 1989; Ratnieks and Reeve 1992; Frank 2003), this idea has never been analyzed formally. The aim of this article is to make a formal analysis of acquiescence and to determine, for a variety of scenarios, when individuals are better off if they do not resist policing. Our analyses explicitly investigate the two main types of policing in social insects, which are also among the best-studied examples of policing in the animal kingdom: policing of egg-laying by workers, that is, the prevention of male production by workers (fig. 1; Ratnieks 1988; Ratnieks and Visscher 1989; Foster and Ratnieks 2000, 2001c), and caste-fate policing, that is, the prevention of immature females from successfully developing into queens rather than workers (fig. 1; Bourke and Ratnieks 1999; Wenseleers et al. 2003; Wenseleers and Ratnieks 2004). The details of each will be discussed below. Although we focus on social insects, we argue that the evolution of acquiescence within social systems is a general process that can reduce conflict and promote cooperation in many other social situations.

\section{Methods}

We use kin selection methods similar to those developed by Frank (1998) to analyze the likelihood that acquiescence can evolve in response to policing. However, unlike Frank (1998) we take an inclusive fitness rather than a direct or neighbor-modulated fitness perspective. Each of the analyses has also been confirmed using allele frequency methods. (See the online edition of the American Naturalist for the Mathematica notebook with kin selection models and equivalent genetic models.) In all cases, the different modeling methods give numerically identical results. It should also be noted that in all models, policing is included as a fixed parameter rather than being allowed to coevolve with the level of intragroup selfishness (Frank 1995, 1998). This is because the evolutionary basis for policing is well understood in each case and we are concerned only with how the presence of policing per se influences the optimal level of selfishness in the group. See table 1 for definitions of model notation and parameters.

\section{Results \\ Worker Sterility as Acquiescence}

In the social Hymenoptera, male production is one of the most important contexts in which conflict can arise. In the majority of species, including most ants, Apis honeybees, Meliponinae stingless bees, and Vespinae wasps, workers retain ovaries even though they cannot mate (Wilson 1971; Bourke 1988). Through the haplodiploid sex determination mechanism found in the Hymenoptera, these workers can lay unfertilized, male-destined eggs and thereby challenge the reproductive primacy of the queen. From an inclusive fitness perspective, worker reproduction is beneficial at the individual level (Hamilton 1964; Trivers and Hare 1976), because any worker is more related to her own sons $(r=0.5)$ than to her brothers, the queen's sons $(r=0.25)$. However, if the queen mates multiple times, as occurs, for example, in the honeybee (Palmer and Oldroyd 2000), then workers are on average more related to queen's sons $(r=0.25)$ than to other workers' sons (full- and half-nephews; $r<0.25$ ). This favors workers to selectively remove or "police" eggs laid by other workers (fig. 1; Ratnieks 1988). Worker policing can also be favored, even when paternity is below two, if it increases colony efficiency (Ratnieks 1988) or if it allows the workers to bias the sex ratio toward females (the worker optimum; Trivers and Hare 1976) at low cost by the removal of males in the egg stage (Foster and Ratnieks 2001b). The queen, from her perspective, always favors the production of her own sons $(r=0.5)$ over workers' sons (her grandsons; $r=0.25$ ). Hence, the queen is also selected to eat workerlaid eggs (queen policing; Trivers and Hare 1976; Ratnieks 1988 ) or to assist in worker policing by marking her eggs with a specific signal (Ratnieks 1995).

Both queen and worker policing are widespread. Worker policing via egg eating is known in several species each of honeybees (fig. 1; Ratnieks and Visscher 1989; Halling et al. 2001; Oldroyd et al. 2001), Vespinae wasps (reviewed in Foster and Ratnieks 2001c), and ants (Kikuta and Tsuji 1999; D’Ettorre et al. 2004; Endler et al. 2004). Queen policing by egg eating occurs in ants (Monnin and Peeters 1997; Kikuta and Tsuji 1999; Monnin et al. 2002), bumblebees (Free et al. 1969; Pomeroy 1979; Cnaani et al. 2002), Dolichovespula and Vespula rufa wasps (Greene 1979; Foster and Ratnieks 2001c; Wenseleers et al. 2005a, 2005b), Polistes paper wasps (Fletcher and Ross 1985; Reeve 1991), and the halictid bee Lasioglossum zephyrum (Michener and Brothers 1974).

Policing can be highly effective. For example, in the honeybee, Apis mellifera, approximately $7 \%$ of all male eggs are laid by workers (Visscher 1996), yet only $0.1 \%$ of all adult males are worker derived (Visscher 1989). This implies that approximately $99 \%$ of all worker-laid eggs are 
Table 1: Notation and parameters used in the models

\begin{tabular}{|c|c|}
\hline Symbol & Definition \\
\hline \multicolumn{2}{|c|}{$\begin{array}{l}\text { Model in "Worker Sterility } \\
\text { as Acquiescence": }\end{array}$} \\
\hline$n$ & Colony size (number of workers) \\
\hline$W_{\mathrm{f}}$ & Total number of males produced by a focal worker in a colony \\
\hline$W_{\mathrm{n}}$ & Total number of males produced by each of the $n-1$ nestmate workers in the colony \\
\hline$W_{\mathrm{mq}}$ & Total number of males produced by the queen \\
\hline$W_{\mathrm{q}}$ & Total number of queens or swarms produced by the colony \\
\hline$x$ & Probability with which a focal worker in a colony activates its ovaries \\
\hline$x^{\prime}$ & Probability with which each of the $n-1$ nestmates activates its ovaries \\
\hline $\bar{x}$ & $\begin{array}{l}\text { Colony average probability with which workers activates its ovaries }=(1-n) x+[(n-1) / \\
n] x^{\prime}\end{array}$ \\
\hline$X$ & Population average proportion of laying workers \\
\hline$X^{*}$ & Evolutionarily stable strategy proportion of reproductive workers \\
\hline$\psi$ & Population-wide proportion of males that are worker produced \\
\hline$q$ & Fecundity of the queen in terms of male production relative to a single reproductive worker \\
\hline$S$ & $\begin{array}{l}\text { Survival of worker-laid eggs relative to queen-laid eggs (declines when they are selectively } \\
\text { killed) }\end{array}$ \\
\hline$P$ & Effectiveness of policing (selective eating of worker eggs) $=1-S$ \\
\hline$R$ & Life-for-life relatedness \\
\hline \multicolumn{2}{|c|}{$\begin{array}{l}\text { Model in "Acquiescence to } \\
\text { Caste Fate": }\end{array}$} \\
\hline$n$ & Number of worker cells present at any one time \\
\hline$q$ & Number of queen cells present at any one time \\
\hline$W_{\mathrm{f}}$ & Expected fitness of a female in a worker cell \\
\hline$W_{\mathrm{n}}$ & Expected fitness of each of the other $n-1$ females in worker cells \\
\hline$W_{\mathrm{q}}$ & Expected fitness of a normal queen developing from a queen cell \\
\hline$W_{\mathrm{m}}$ & Total number of males produced by the colony \\
\hline$y$ & Probability with which a focal female in a worker cell develops as a queen \\
\hline$y^{\prime}$ & Probability with which each of the $n-1$ other females in worker cells develops as a queen \\
\hline $\bar{y}$ & $\begin{array}{l}\text { Colony average probability with which female larvae in worker cells develop as queens }=(1- \\
\qquad n) y+[(n-1) / n] y^{\prime}\end{array}$ \\
\hline$Y$ & Population average probability of developing as a queen when in a worker cell \\
\hline$Y^{*}$ & Evolutionarily stable strategy probability of developing as a queen when in a worker cell \\
\hline$S$ & Survival of small queens relative to normal queens (declines when they are selectively killed) \\
\hline$P$ & Effectiveness of policing (selective elimination of queens developing in worker cells) $=1-S$ \\
\hline$R_{\mathrm{f}}$ & Life-for-life relatedness to sister queens reared in the colony \\
\hline$R_{\mathrm{m}}$ & Life-for-life relatedness to males reared in the colony \\
\hline
\end{tabular}

policed. Does this high policing effectiveness reduce the incentive for workers to lay eggs, as several authors have suggested (e.g., Ratnieks 1988; Visscher 1989; Ratnieks and Reeve 1992)? For example, could it explain why so few workers in queenright colonies (approximately 0.1\%$0.01 \%$ ) have active ovaries (Ratnieks 1993)? If so, this would be a good example of acquiescence.

The following model investigates whether effective policing can cause acquiescence. Let $n$ be the number of workers in the colony, $S$ the survival of worker-laid male eggs relative to queen-laid male eggs (which is reduced by both queen or worker policing but unaffected by random egg mortality), and $q$ the fecundity of the queen relative to a single reproductive worker in terms of laying male eggs. Assume that a focal worker in a colony activates her ovaries to lay eggs with probability $x$ and that each of its $n-1$ nestmates activate their ovaries with probability $x^{\prime}$ so that the colony contains $n \bar{x}$ egg-laying workers, where $\bar{x}$ is the average probability with which workers activate their ovaries, $\bar{x}=(1 / n) x+[(n-1) / n] x^{\prime}$. We can now write the total number of males produced by this focal worker and by each nestmate worker as

$$
\begin{aligned}
& W_{\mathrm{f}}=G(\bar{x}) \times \frac{x S}{n \bar{x} S+q}, \\
& W_{\mathrm{n}}=G(\bar{x}) \times \frac{x^{\prime} S}{n \bar{x} S+q},
\end{aligned}
$$

where $G(\bar{x})$ is the colony productivity (total number of 
males reared) as a function of how many laying workers there are in the colony (egg-laying workers generally perform less work and so decrease total colony productivity; Michener and Brothers 1974; Landolt et al. 1977; van Honk and Hogeweg 1981; Ward 1983; Cole 1986; Hillesheim et al. 1989; Reeve 1991; Monnin and Peeters 1999; Hartmann and Heinze 2003). The following term represents the proportion of all males that are workers' sons. That is, the total number of sons of the focal and other workers that survive policing ( $x S$ or $\left.x^{\prime} S\right)$, divided by all surviving males, which includes both workers' sons $(n \bar{x} S)$ and queen's sons, laid in proportion to the relative rate $q$ at which these are produced. For simplicity, we will assume that worker reproduction linearly reduces colony productivity, that is, $G=1-\bar{x}$.

By a similar argument, the total number of males produced by the queen is

$$
W_{\mathrm{mq}}=G(\bar{x}) \times \frac{q}{n \bar{x} S+q} .
$$

Finally, the total amount of female reproduction by the colony (winged queens, or swarms for swarm-founding species such as honeybees) is also a decreasing function of $\bar{x}$. For simplicity, we assume that worker reproduction reduces queen and male production equally. Hence, the total number of queens or swarms produced is

$$
W_{\mathrm{q}}=G(\bar{x})=1-\bar{x} .
$$

To calculate the evolutionarily stable strategy (ESS) proportion of workers who activate their ovaries we need to calculate the inclusive fitness gained by a focal worker who has a marginally greater probability of reproducing than other workers. This can be calculated following Frank (1998) as

$$
\begin{aligned}
& \left.\frac{\partial \mathrm{W}_{\mathrm{f}}}{\partial x}\right|_{x, x^{\rightarrow} \rightarrow X} \times R_{\text {son }}+(n-1) \times\left.\frac{\partial W_{\mathrm{n}}}{\partial x}\right|_{x, x^{\prime} \rightarrow X} \times R_{\text {nephew }} \\
& +\left.\frac{\partial W_{\mathrm{mq}}}{\partial x}\right|_{x, x^{\prime} \rightarrow X} \times R_{\text {brother }}+\left.\frac{\partial W_{\mathrm{q}}}{\partial x}\right|_{x, x^{\prime} \rightarrow X} \times R_{\text {sister }} .
\end{aligned}
$$

This is a Hamilton's rule condition (Hamilton 1964) in which the derivatives measure how greater reproduction by the focal worker affects the production of various classes of kin (sons of the focal worker, nephews produced by the $n-1$ nestmate workers, and brothers and sisters produced by the mother queen; Frank 1998). The $R$ values are the life-for-life relatednesses to each class of offspring. The derivatives are evaluated for the case where the workers' behavior approaches that of the rest of the population, $\left(x, x^{\prime} \rightarrow X\right)$, because we need to determine the invasion condition for a mutant that is only marginally different in phenotype from the common type (Frank 1998). Lifefor-life relatedness is the product of regression relatedness, a measure of the proportion of genes the recipient has in common with the actor relative to a random individual and sex-specific reproductive value, a measure of the genetic contribution of a given sex to the future gene pool (Pamilo 1991). Hence, the $R$ values can be expanded to $R_{\text {son }}=r_{\text {son }} \times \nu_{\mathrm{m}}=1 \times \nu_{\mathrm{m}}, \quad R_{\text {nephew }}=r_{\text {sister }} \times \nu_{\mathrm{m}}, \quad$ and $R_{\text {brother }}=r_{\text {brother }} \times \nu_{\mathrm{m}}=(1 / 2) \times \nu_{\mathrm{m}}$, where $\nu_{\mathrm{m}}$ is the relative reproductive value of males to females, which is $1 /(2-\psi)$, where $\psi$ is the population-wide proportion of males that are workers' sons (Pamilo 1991). In our case, it can be seen that $\psi=n X S /(n X S+q)$, where $X$ is the average proportion of laying workers in an average colony in the population.

An evolutionarily stable strategy (Maynard Smith 1982) occurs when there is no net inclusive fitness gain from increased or decreased worker reproduction; that is, when equation $(5)=0$. Calculating the partial derivatives (see the Mathematica notebook) and solving for $X$ shows that this occurs when the proportion of laying workers is

$$
X^{*}=\frac{-B+\sqrt{B^{2}-4 A C}}{2 A},
$$

with

$$
\begin{aligned}
A= & 2 n^{2} S^{2}\left(1+R_{\text {sister }}\right), \\
B= & 2 S\left[q\left(1+n-R_{\text {sister }}+4 n R_{\text {sister }}\right)\right. \\
& \left.+(n-1) n\left(1-R_{\text {sister }}\right) S\right], \\
C= & q\left[q\left(1+4 R_{\text {sister }}\right)-n S\right] .
\end{aligned}
$$

Because effective policing reduces the survival of worker-laid eggs, we can substitute $1-P$ for $S$ in the above equation, where $P$ is the effectiveness of policing. The ESS proportion of laying workers increases under three conditions: first, with lower relatedness among sisters because low sister-sister relatedness increases the relatedness gain of replacing nephews by sons (cf. Bourke 1988); second, with greater colony size because competition over male production will then primarily be with other workers rather than with the queen; third, with increasing male egg production by the queen (the reverse argument). Importantly, the ESS proportion of laying workers declines as the effectiveness of the policing increases (fig. 2a). Intuitively, this is because the benefit to a worker of laying $\left(\partial W_{\mathrm{f}} / \partial x \mid x, x^{\prime} \rightarrow X\right)$ declines when fewer of her eggs are reared. This supports the idea that policing of worker-laid 
(a)

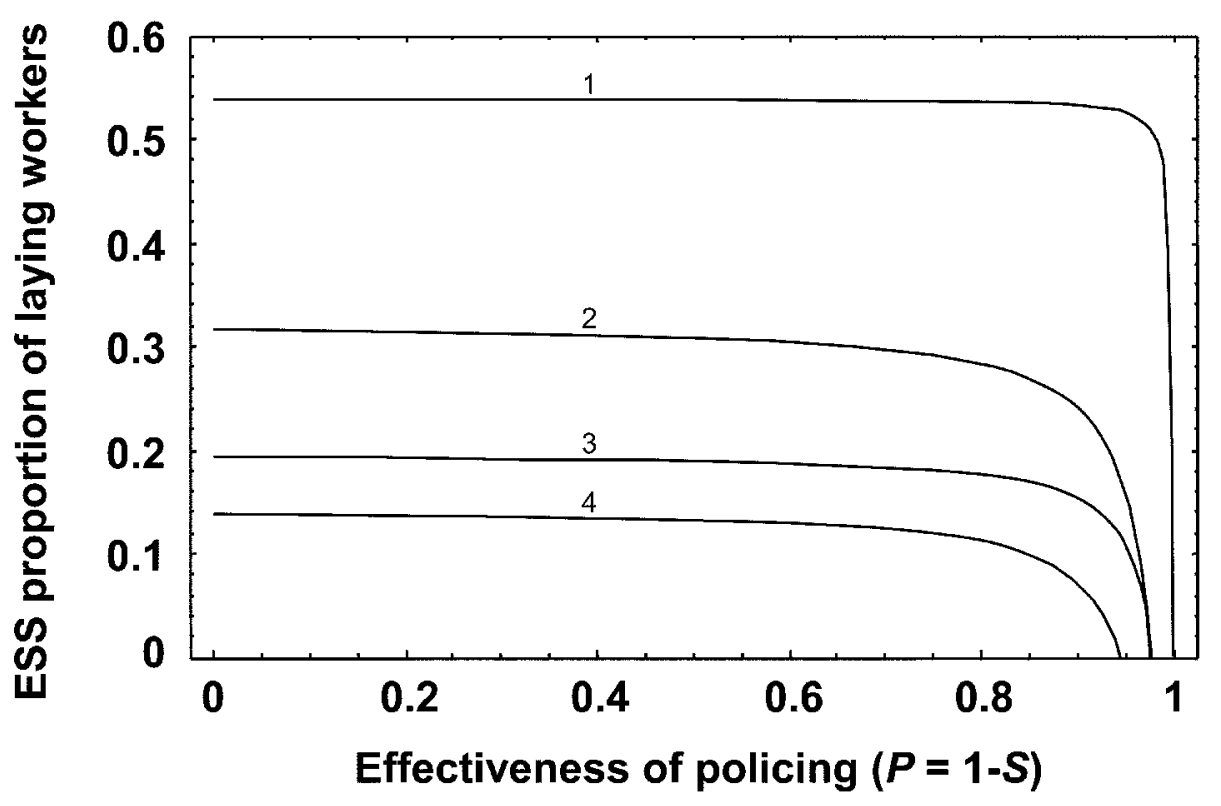

(b)

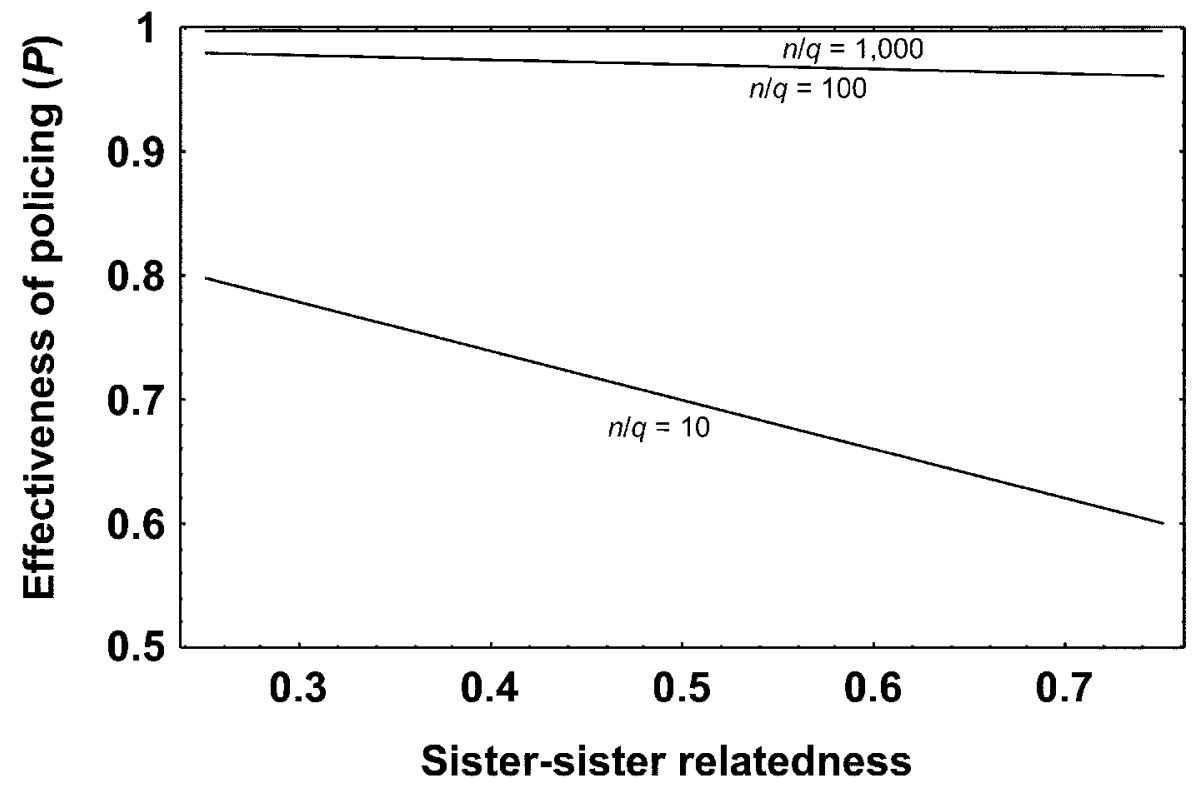

Figure 2: Acquiescence in the context of conflict over male parentage. $a$, Evolutionarily stable strategy (ESS) proportion of egg-laying workers (eq. $[6])$ as a function of the relative probability $P$ with which worker-laid eggs are killed (policed) relative to queen-laid eggs. The curves are drawn for parameter values that apply to worker policing in the honeybee Apis mellifera ( 1 , multiple mating, $r=0.3, n=35,000$ workers, relative queen fecundity $q=25$ ), the common wasp Vespula vulgaris (2, double mating, $r=0.51, n=3,000$ workers, relative queen fecundity $q=25$ ), and the European hornet Vespa crabro (3, mostly single mating, $r=0.67, n=400$ workers, relative queen fecundity $q=2.5$ ), and to queen policing in Dolichovespula maculata (4, single mating, $r=0.75, n=180$ workers, relative queen fecundity $q=2.5$ ). Note how the ESS declines as the efficiency of policing approaches $100 \%$. For example, for $P>99.8 \%$ in honeybees and for $P>97.7 \%$ in the hornet, it becomes unprofitable for any worker to reproduce. This shows that policing can select for workers to completely refrain from egg laying. Parameter values are from Seeley (1985), Ratnieks (1993), Foster and Ratnieks (2001a), Foster et al. (2002), and T. Wenseleers (unpublished data). $b$, Critical efficiency of policing required to favor complete worker sterility as a function of sister-sister relatedness and for different $n: q$ ratios (colony size/relative queen fecundity). 
eggs selects for self-policing or acquiescence (Ratnieks 1988; Visscher 1989).

If the effectiveness of policing is high enough, workers are selected to completely refrain from egg laying. That is, all workers acquiesce by showing complete reproductive restraint. The conditions under which this should occur can be determined by evaluating costs and benefits of worker reproduction in a population where worker reproduction is absent, that is, $X=0$. Substitution of $X=0$ in equation (5) shows that worker laying can only invade when

$$
\frac{S}{q} \times\left(R_{\text {son }}-R_{\text {brother }}\right)-\frac{1}{n} \times R_{\text {brother }}-\frac{1}{n} \times R_{\text {sister }}>0 .
$$

This equation has the intuitive interpretation that a single laying worker in a colony would replace a fraction $S /$ $q$ of the queen's male eggs by sons but would diminish total colony reproduction by $1 / n$ if it did no work. From equation (7) it is clear that complete reproductive restraint occurs when the survival of worker eggs is lower than

$$
\begin{aligned}
S_{\text {crit }} & =\frac{R_{\text {brother }}+R_{\text {sister }}}{(n / q)\left(R_{\text {son }}-R_{\text {brother }}\right)} \\
& =\frac{1 / 4+R_{\text {sister }}}{(n / q)(1 / 4)} \\
& =\frac{1+4 R_{\text {sister }}}{(n / q)}
\end{aligned}
$$

or when the effectiveness of policing $P(=1-S)$ is greater than $1-S_{\text {crit }}$. The critical policing effectiveness required for complete worker acquiescence under different degrees of relatedness among workers and for different $n$ to $q$ ratios are shown in figure $2 b$.

Figure $2 a$ illustrates numerically how policing reduces the ESS proportion of egg-laying workers for parameter values that apply to three well-characterized systems of worker policing - the honeybee Apis mellifera (Ratnieks and Visscher 1989), the common wasp Vespula vulgaris (Foster and Ratnieks 2001a), and the European hornet Vespa crabro (Foster et al. 2002) —and one system of queen policing, in the wasp Dolichovespula maculata (Greene 1979). All four species have very low levels of worker reproduction, with $<2 \%$ of the workers having active ovaries (Ratnieks 1993; Foster and Ratnieks 2001a; Foster et al. 2001, 2002). It is clear from our analysis that such low levels of worker reproduction must be evolutionary responses to policing and not to kinship alone. Queens in both the honeybee and the common wasp are polyandrous (Palmer and Oldroyd 2000; Foster and Ratnieks 2001a), which reduces relatedness among female offspring (Apis, $r=0.3$, Palmer and Oldroyd 2000; V. vulgaris, $r=0.5$, Foster and Ratnieks 2001a). The model predicts that with such relatedness values and in the absence of policing, a very high proportion of the workers should reproduce: $\sim 56 \%$ in Apis and $\sim 33 \%$ in Vespula. Similarly, the optimum proportion of reproductive workers, in the absence of policing, would be $\sim 19 \%$ in Vespa crabro and $\sim 14 \%$ in Dolichovespula maculata (fig. $2 a$ ). The much smaller observed proportion of reproductive workers in these species, $<2 \%$ (Ratnieks 1993; Foster and Ratnieks 2001b; Foster et al. 2001, 2002), is probably a response to the effective policing that occurs in these species (fig. $2 a$ ).

\section{Acquiescence to Caste Fate}

In social Hymenoptera, social policing can also occur in other areas of reproduction besides male production, including the conflict over female caste fate (Bourke and Ratnieks 1999; Ratnieks 2001; Wenseleers et al. 2003). Advanced eusocial species are characterized by the presence of a caste system in which immature females irreversibly develop as one of two morphologically distinct castes, queen or worker (Wilson 1971). Because queens have much greater reproductive potential than workers, an immature female generally benefits from developing as a queen rather than as a worker (Bourke and Ratnieks 1999; Ratnieks 2001; Reuter and Keller 2001; Strassmann et al. 2002; Wenseleers et al. 2003). However, her fate is normally out of her own control, being socially imposed by the amount or quality of food she is fed as a larva by the adult workers (Wheeler 1986; Bourke and Ratnieks 1999; Beekman and Ratnieks 2003; Beekman et al. 2003). The prevention of individuals from selfishly developing as queens is referred to as caste-fate policing (Wenseleers et al. 2003).

But why should developing females accept the fate imposed on them and develop as workers in response to reduced feeding? In several stingless bee genera, females reared in worker cells overcome feeding control by developing as worker-sized "dwarf queens" (reviewed in Engels and Imperatriz-Fonseca 1990; Imperatriz-Fonseca and Zucchi 1995; Wenseleers et al. 2003, 2005c). In this way, they can successfully circumvent caste-fate policing. Similarly, in many ant species, females can sometimes develop as small intercaste queens (Heinze 1998). Given the immature females in some species can overcome caste-fate policing, why should females acquiesce to their imposed feeding regime and not develop as dwarf queens in all species?

One likely reason is that a dwarf queen may not get the full reproductive benefit of a normal-sized queen. Indeed, in the stingless bee Schwarziana quadripunctata, dwarf queens are less fecund than normal queens (Ribeiro and Alves 2001; Wenseleers et al. 2005c). If the lifetime fe- 
cundity of dwarf queens were less than $75 \%$ that of normal queens, then under single mating and monandry, it is better to develop into a worker than into a dwarf queen because producing $100 \%$ of a full sister's offspring $(r=$ 0.375 ) would be as good as producing $75 \%$ as many one's own offspring $(r=0.5)$. This cost of becoming a dwarf queen could select against cheating and favor females to acquiesce to their intended worker fate.

An additional condition under which acquiescence may be expected is when queens compete locally, as occurs in species with swarm-founded colonies such as honeybees and stingless bees. In swarm-founding species, queens reared in worker cells would probably have a competitive disadvantage over normal-sized queens, particularly if workers prefer normal rather than undersized queens to head new swarms or if dwarf queens have a reduced fighting ability. Worker discrimination against dwarf queens appears to occur in S. quadripunctata. Whereas large queens are preferentially stored in special "queen prison" cells, potentially to head a colony at a later date (Imperatriz-Fonseca and Kleinert-Giovannini 1989; ImperatrizFonseca 1990), most dwarf queens are eliminated by the workers (Imperatriz-Fonseca and Kleinert-Giovannini 1989; Imperatriz-Fonseca 1990; Wenseleers et al. 2005c). Consequently, the proportion of dwarf queens heading colonies $(22 \%)$ is much lower than the rate at which they are reared (86\%, Wenseleers et al. 2005c).

Could discrimination against dwarf queens by workers make developing as a dwarf queen less rewarding, similar to the way that egg policing makes it less rewarding for workers to lay eggs? To investigate this, consider the following model, which is an extension of a previous model (Wenseleers et al. 2003).

Let $n$ and $q$ be the number of worker and queen cells present at any one time in the colony and $S$ be the survival of dwarf queens reared in worker cells relative to normal queens reared in queen cells ( $S$ declines when workers selectively kill small queens). Assume that a focal female in a worker cell cheats by developing into a dwarf queen with probability $y$ and that each of the $n-1$ females in worker cells cheat with an average probability of $y^{\prime}$. If normal and small queens engage in a scramble competition to form new swarms, then it can be shown (app. A) that the ESS proportion of females in worker cells that should develop as queens is

$$
Y^{*}=\frac{-B+\sqrt{B^{2}-4 A C}}{2 A},
$$

with

$$
\begin{aligned}
A= & n^{2} S^{2}\left(1+R_{\mathrm{m}}\right), \\
B= & S\left\{q\left[1+n-2 n R_{\mathrm{m}}-(1-n) R_{\mathrm{f}}\right]\right. \\
& \left.+(n-1) n\left(1-R_{\mathrm{f}}\right) S\right\}, \\
C= & q\left[q\left(R_{\mathrm{m}}+R_{\mathrm{f}}\right)-n\left(1-R_{\mathrm{f}}\right) S\right],
\end{aligned}
$$

where $R_{\mathrm{m}}$ and $R_{\mathrm{f}}$ are the (life-for-life) relatedness to males and queens reared in the colony.

Plotting equation (9) shows that more females in worker cells should develop as queens when either the relatedness among sisters $\left(R_{\mathrm{f}}\right)$ or the relatedness to the males $\left(R_{\mathrm{m}}\right)$ reared in the colony is lower (fig. 3). The presence of many worker cells (high $n$ ) or few queen cells (low $q$ ) also heightens the conflict and favors more females in worker cells to develop as queens. This is because it shifts the queenqueen competition to being primarily among the females developing in workers cells. However, as before, the presence of a policing mechanism, here in the form of the selective elimination of small queens, can favor individuals to acquiesce and deliberately accept their intended worker fate.

If the probability that small queens are killed is sufficiently high (i.e., if $S$ is low or if $P$ is high), then females in worker cells can be selected to completely acquiesce and never attempt to develop as a queen. As before, the conditions under which this should occur can be determined by calculating when females in worker cells are selected to cheat and become queens in a situation in which the strategy is initially absent. This is the case when

$$
\frac{S}{q} \times\left(1-R_{\mathrm{f}}\right)-\frac{1}{n} \times R_{\mathrm{f}}-\frac{1}{n} \times R_{\mathrm{m}}>0 .
$$

Inequality equation (10) has the intuitive interpretation that a single female that would develop as a queen rather than a worker would win out over normal queens during colony founding with probability $S / q$ (because it would survive with probability $S$ but competes with $q$ normal queens) but that her loss to the workforce would reduce the productivity of the colony (male and swarm production) by a fraction $1 / n$. From equation (10), it is clear that female larvae in worker cells are never selected to become queens when the survival of dwarf queens is less than

$$
S_{\text {crit }}=\frac{R_{\mathrm{m}}+R_{\mathrm{f}}}{(n / q)\left(1-R_{\mathrm{f}}\right)}
$$

or when the effectiveness of policing $P(=1-S)$ is greater than $1-S_{\text {crit }}$. This critical efficiency of policing required to favor complete caste-fate acquiescence, for different relatedness values and for different $n: q$ ratios, is shown in figure $3 b$. 
(a)

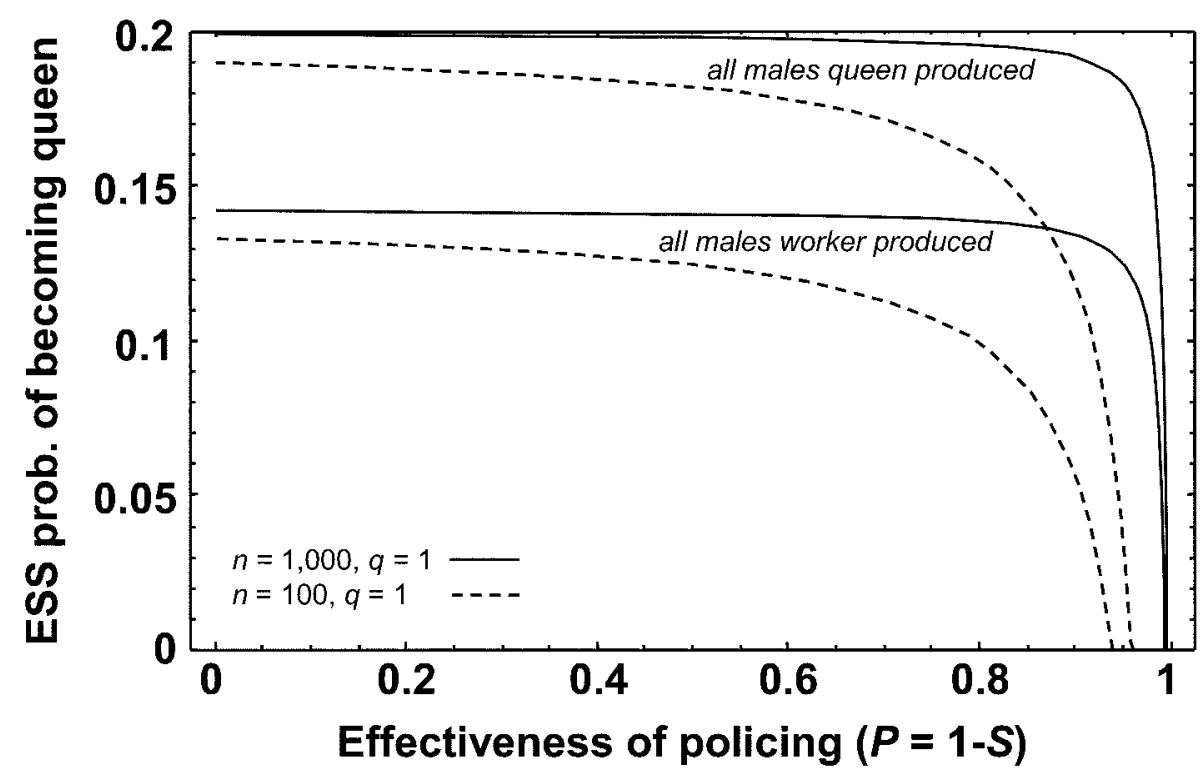

(b)

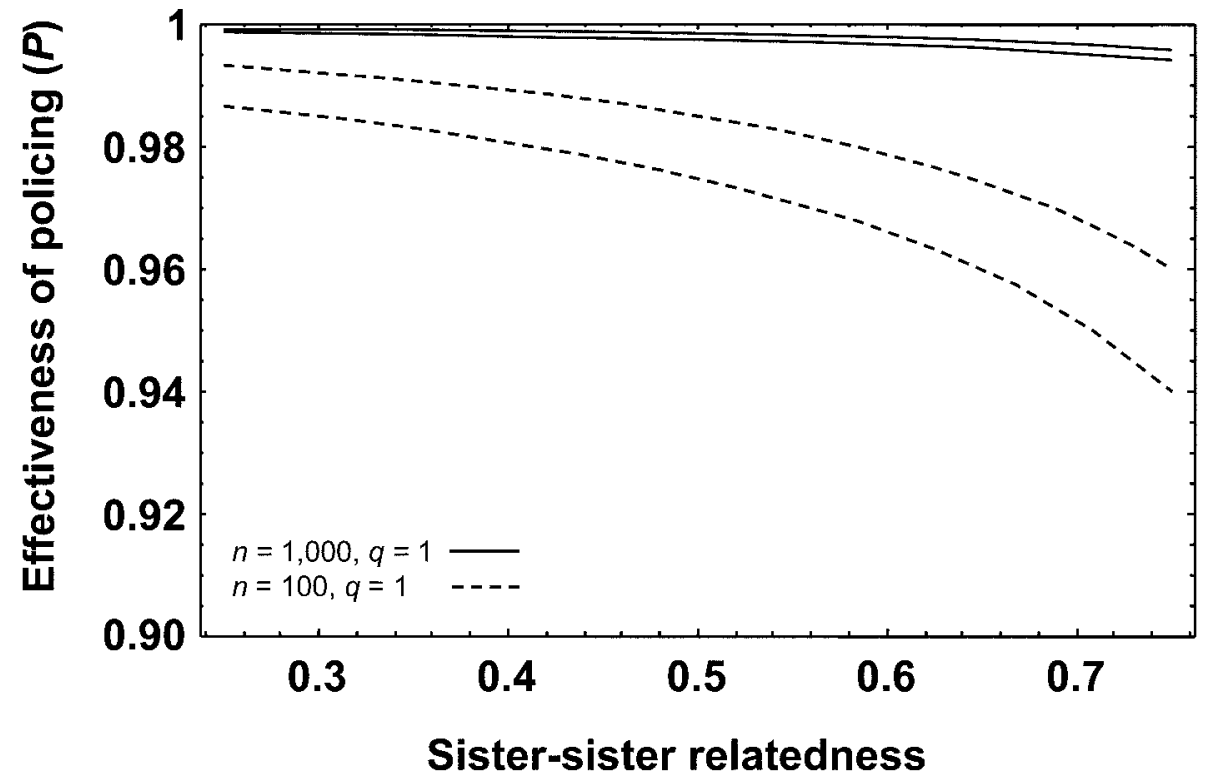

Figure 3: Acquiescence in the context of conflict over caste fate in swarming social Hymenoptera such as stingless bees or honeybees. $a$, Evolutionarily stable strategy (ESS) proportion of females in worker cells that should develop as queens (eq. [9]) reduces as the effectiveness of policing increases (in the form of discrimination against dwarf queens reared in worker cells). The ESS is plotted for the situation of single mating $\left(R_{\mathrm{f}}=0.75\right.$ ), as is typical for stingless bees (Peters et al. 1999), with all males being either queen's sons $\left(R_{\mathrm{m}}=0.25\right.$; top two curves $)$ or workers' sons $\left(R_{\mathrm{m}}=0.75\right.$; bottom two curves) and with either $1: 1,000$ (solid lines) or $1: 100$ (dashed lines) cells being specialized queen cells (number of worker cells $n=$ 100 or 1,000 for every queen cell that is built). $b$, Critical effectiveness of policing required to make it completely unprofitable for females in worker cells to develop as queens, plotted as a function of sister-sister relatedness, with all males being either queen's sons $\left(R_{\mathrm{m}}=0.25\right.$; top solid and dashed curves) or workers' sons $\left(R_{\mathrm{m}}=0.75\right.$; bottom solid and dashed curves) and with either $1: 1,000$ (solid lines) or $1: 100$ (dashed lines) cells being specialized queen cells. 
Support for these predictions is provided by patterns of queen production in different genera of stingless bees. In the genus Melipona, normal-sized queens reared from specialized queen cells are absent $(q=0)$. Instead, all queens and workers (and males) develop in identically sized cells on a similarly sized provision mass (Engels and ImperatrizFonseca 1990; Wenseleers et al. 2004). Furthermore, castefate policing is impossible $(P=0)$ as queen development is unconstrained by nutrition (Kerr 1950; Wenseleers et al. 2003, 2004, 2005c). In line with prediction, a very large proportion, 5\%-14\%, of Melipona females selfishly develop into queens (Kerr 1950; Wenseleers and Ratnieks 2004). By contrast, in stingless bees where queens are normally reared from larger royal cells, few or zero females in worker cells develop as queens (Engels and ImperatrizFonseca 1990; Imperatriz-Fonseca and Zucchi 1995; Ribeiro et al. 2003). For example, in S. quadripunctata, just $0.6 \%$ of all females in worker cells become dwarf queens (Wenseleers et al. 2005c). This is as predicted given that dwarf queens are less fecund (Ribeiro and Alves 2001; Wenseleers et al. 2005c) and that as a result of selective culling by workers (fig. 1), their survival $S$ is only $(0.22 / 0.86)[(1-0.86) /(1-0.22)]=4.6 \%$ that of normal queens (cf. Ribeiro and Alves 2001; Wenseleers et al. 2005c; and data cited above). Fecundity costs are probably also the reason why the honeybee females in worker cells never develop as small queens: the fecundity of such queens would almost certainly be too low to sustain their large colonies of over 35,000 bees (Seeley 1985; Winston 1987). In addition, and unlike in stingless bees, larvae are reared in open cells in the honeybee (Winston 1987), which would enable workers to kill larvae attempting to develop into queens at an early age.

\section{Discussion}

Social policing is a key mechanism for reducing conflict and promoting cooperation within social groups (Ratnieks 1988, 2000; Ratnieks and Visscher 1989; Ratnieks and Reeve 1992; Frank 1995, 1996; Bourke and Ratnieks 1999; Monnin and Ratnieks 2001). However, our analysis shows that policing may be far more effective at reducing conflict than previously realized. Not only can policing prevent individuals from acting selfishly, it can also make it worthless for them even to try to act selfishly in the first place. This can favor societies where most individuals acquiesce by adopting a less-favored position or strategy in society. We examined two major conflict scenarios found in the eusocial Hymenoptera, and in both cases, effective policing can make resistance largely or completely useless. This is a very significant finding because it helps to resolve major long-standing issues at the heart of eusociality: the evolution and maintenance of repro- ductive division of labor, in particular why most workers who retain ovaries do not use them and why most totipotent female larvae develop into workers and not queens (Darwin 1859; Hamilton 1964; Trivers and Hare 1976). Empirically, acquiescence can explain the observed low levels of reproductive workers found in insect societies with effective policing, such as the honeybee (Ratnieks 1993) or the common wasp (Foster and Ratnieks $2001 a$ ), and the rarity by which females cheat on their intended worker fate, which only occurs at low levels in a minority of genera (e.g., in some stingless bees; Engels and Imperatriz-Fonseca 1990; Imperatriz-Fonseca and Zucchi 1995; Ribeiro and Alves 2001; Wenseleers et al. 2003; Wenseleers et al. 2005c) and is entirely absent in most (e.g., in the honeybee; Winston 1987). The ultimate endpoint of acquiescence is the evolution of obligate worker sterility in some species, for example, in Atta, where workers are unable to lay viable eggs (M. Dijkstra, personal communication) and in Linepithema, Monomorium, Pheidole, and Solenopsis ants and Frieseomellitta and Duckeola stingless bees, where workers have evolutionarily lost ovaries altogether (Oster and Wilson 1978; Cruz-Landim 2000). However, because it is currently unknown whether these genera ancestrally had queen or worker policing, we cannot test whether worker sterility has indeed evolved in response to policing or whether alternative factors may have been the main cause.

Given the large and complex societies found in many eusocial Hymenoptera, it it perhaps unsurprising that they should provide such clear examples of acquiescence. Nevertheless, acquiescence may also be expected in other social situations such as in vertebrate societies (Emlen 1991; Keller and Reeve 1994) or in the parent-offspring relationship (Mock and Parker 1998). For example, if parents do not respond to excessive levels of begging, this would favor more obedient, acquiescent young (Mock and Parker 1998). Similarly, in cooperatively breeding animals, manipulation by dominants can impose costs on subordinates, favoring them to stay and help rather than leave, that is, acquiesce (Crespi and Ragsdale 2000). These examples indicate that acquiescence could well be a very widespread mechanism for conflict reduction in societies.

\section{Acknowledgments}

This work was supported by the Integrated Studies of the Economics of Insect Societies-European Union Training and Mobility of Researchers Network, by a Marie Curie postdoctoral fellowship to T.W., and by Natural Environment Research Council grant NER/A/S/2000/01324 to A.G.H. We thank S. Frank for discussion and advice on parts of the analyses. We are also very grateful to V.-L. 
Imperatriz-Fonseca for making Schwarziana colonies available for photography.

\section{APPENDIX A}

\section{Derivation of the ESS Production of Cheating Queens}

Let $n$ and $q$ be the number of worker and queen cells present at any one time in the colony and $S$ be the survival of dwarf queens reared in worker cells relative to normal queens reared in queen cells (dwarf queen survival declines when workers discriminate against them). Assume that a focal female in a worker cell develops as a queen rather than as a worker with probability $y$ versus probability $y^{\prime}$ for the other $n-1$ females. The colony will then, at any one time, produce normal queens from queen cells at a rate proportional to $q$ and small queens from worker cells at a rate proportional to $n \bar{y}$, if $\bar{y}$ is the average probability with which females in worker cells develop as queens, $\bar{y}=(1 / n) y+[(n-1) / n] y^{\prime}$. Also assume, for simplicity, that small queens reared from worker cells do not have reduced fecundity relative to normal queens (including fecundity in the model greatly complicates the analysis because it would be necessary to keep track of the proportions of colonies in the population that are headed by small vs. normal queens).

The probability that queens reared in worker cells will successfully head a new colony is proportional to

$$
W_{\mathrm{f}}=G(\bar{y}) \times \frac{y S}{n \bar{y} S+q}
$$

and

$$
W_{\mathrm{n}}=G(\bar{y}) \times \frac{y^{\prime} S}{n \bar{y} S+q},
$$

where $G(\bar{y})$ is the colony productivity (relative number of new swarms formed) as a function of how many females become queens rather than workers. The term following this represents the proportion of all new queens who were reared in worker cells, which is given by the probability that each one develops as a queen (probability $y$ or $y^{\prime}$ ) and survives (probability $S$ ) divided by the total number of surviving small queens $(n \bar{y} S)$ plus the number of normal queens $(q)$ produced. For simplicity, we will assume that colony productivity declines linearly with the proportion of females that develop into queens rather than workers, $G=1-\bar{y}$. Note that these equations have the same form as in the worker reproduction model (see "Worker Sterility as Acquiescence") but with the parameters suitably redefined.
By a similar argument, the expected fitness of queens reared in queen cells is proportional to

$$
W_{\mathrm{q}}=G(\bar{y}) \times \frac{1}{n \bar{y} S+q} .
$$

Finally, fitness through male production $W_{\mathrm{m}}$ is also a decreasing function of $\bar{y}$ :

$$
W_{\mathrm{m}}=G(\bar{y})=1-\bar{y}
$$

To calculate the ESS, we need to calculate the inclusive fitness gained by females in worker cells who alter their probability of developing as a queen, which can be calculated as (Frank 1998)

$$
\begin{aligned}
& \left.\frac{\partial \mathrm{W}_{\mathrm{f}}}{\partial y}\right|_{y, y \rightarrow Y} \times R_{\text {self }}+(n-1) \times\left.\frac{\partial W_{\mathrm{n}}}{\partial y}\right|_{y, y \rightarrow Y} \times R_{\text {sister }} \\
& +q \times\left.\frac{\partial W_{\mathrm{g}}}{\partial y}\right|_{y, y \rightarrow Y} \times R_{\text {sister }}+\left.\frac{\partial W_{\mathrm{m}}}{\partial y}\right|_{y, y \rightarrow Y} \times R_{\text {males }} .
\end{aligned}
$$

As in "Worker Sterility as Acquiescence," this is a Hamilton's rule condition (Hamilton 1964) in which the derivatives measure how the behavior of the focal female in a worker cell affects the fitness or production of various classes of kin (self, sister females in $n-1$ other worker cells, sister queens in $q$ queen cells, and males produced by either the queen or the workers), and the $R$ values measure the life-for-life relatednesses to each of them. Calculating the partial derivatives and solving when the resulting equation is 0 yields the ESS given in equation (9) (see the Mathematica notebook and code).

\section{Literature Cited}

Beekman, M., and F. L. W. Ratnieks. 2003. Power over reproduction in social Hymenoptera. Philosophical Transactions of the Royal Society of London B 358: 1741-1753.

Beekman, M., J. Komdeur, and F. L. W. Ratnieks. 2003. Reproductive conflicts in social animals: who has power? Trends in Ecology \& Evolution 18:277-282.

Bourke, A. F. G. 1988. Worker reproduction in the higher eusocial Hymenoptera. Quarterly Review of Biology 63: 291-311.

Bourke, A. F. G., and F. L. W. Ratnieks. 1999. Kin conflict over caste determination in social Hymenoptera. Behavioral Ecology and Sociobiology 46:287-297.

Cnaani, J., R. Schmid-Hempel, and J. O. Schmidt. 2002. Colony development, larval development and worker reproduction in Bombus impatiens Cresson. Insectes Sociaux 49:164-170.

Cole, B. J. 1986. The social behavior of Leptothorax allar- 
dycei (Hymenoptera, formicidae): time budgets and the evolution of worker reproduction. Behavioral Ecology and Sociobiology 18:165-173.

Crespi, B. J., and J. E. Ragsdale. 2000. A skew model for the evolution of sociality via manipulation: why it is better to be feared than loved. Proceedings of the Royal Society of London B 267:821-828.

Cruz-Landim, C. 2000. Ovarian development in Meliponine bees (Hymenoptera: Apidae): the effect of queen presence and food on worker ovary development and egg production. Genetics and Molecular Biology 23:8388.

Darwin, C. R. 1859. On the origin of species. J. Murray, London.

D'Ettorre, P., J. Heinze, and F. L. W. Ratnieks. 2004. Worker policing by egg-eating in the ponerine ant, Pachycondyla inversa. Proceedings of the Royal Society of London B 271:1427-1434.

Emlen, S. T. 1991. Evolution of cooperative breeding in birds and mammals. Pages 301-337 in J. Krebs and N. B. Davies, eds. Behavioural ecology: an evolutionary approach. Blackwell Scientific, Oxford.

Endler, A., J. Liebig, T. Schmitt, J. E. Parker, G. R. Jones, P. Schreier, and B. Hölldobler. 2004. Surface hydrocarbons of queen eggs regulate worker reproduction in a social insect. Proceedings of the National Academy of Sciences of the USA 101:2945-2950.

Engels, W., and V. L. Imperatriz-Fonseca. 1990. Caste development, reproductive strategies, and control of fertility in honey bees and stingless bees. Pages 167-230 in W. Engels, ed. Social insects: an evolutionary approach to castes and reproduction. Springer, Berlin, Heidelberg.

Fletcher, D. J. C., and K. G. Ross. 1985. Regulation of reproduction in eusocial Hymenoptera. Annual Review of Entomology 30:319-343.

Foster, K. R., and F. L. W. Ratnieks. 2000. Facultative worker policing in a wasp. Nature 407:692-693.

- 2001a. Convergent evolution of worker policing by egg eating in the honeybee and common wasp. Proceedings of the Royal Society of London B 268:169-174.

- 2001b. The effect of sex-allocation biasing on the evolution of worker policing in hymenopteran societies. American Naturalist 158:615-623.

- 2001c. Paternity, reproduction and conflict in vespine wasps: a model system for testing kin selection predictions. Behavioral Ecology and Sociobiology 50:18.

Foster, K. R., F. L. W. Ratnieks, N. Gyllenstrand, and P. A. Thoren. 2001. Colony kin structure and male production in Dolichovespula wasps. Molecular Ecology 10: 1003-1010.

Foster, K. R., J. Gulliver, and F. L. W. Ratnieks. 2002.
Worker policing in the European hornet Vespa crabro. Insectes Sociaux 49:41-44.

Frank, S. A. 1995. Mutual policing and repression of competition in the evolution of cooperative groups. Nature 377:520-522.

. 1996. Policing and group cohesion when resources vary. Animal Behaviour 52:1163-1169.

- 1998. The foundations of social evolution: monographs in behavior and ecology. Princeton University Press, Princeton, N.J.

- 2003. Repression of competition and the evolution of cooperation. Evolution 57:693-705.

Free, J. B., I. Weinberg, and A. Whiten. 1969. The eggeating behavior of Bombus lapidarius L. Behaviour 35: 313-317.

Greene, A. 1979. Behavioural characters as indicators of yellowjacket phylogeny (Hymenoptera: Vespidae). Annals of the Entomological Society of America 72:614619.

Halling, L. A., B. P. Oldroyd, W. Wattanachaiyingcharoen, A. B. Barron, P. Nanork, and S. Wongsiri. 2001. Worker policing in the bee Apis florea. Behavioral Ecology and Sociobiology 49:509-513.

Hamilton, W. D. 1964. The genetical evolution of social behavior. I, II. Journal of Theoretical Biology 7:1-52.

- 1995. Narrow roads of gene land. Vol. 1. Evolution of social behavior. W. H. Freeman, New York.

Hardin, G. 1968. The tragedy of the commons. Science 162:1243-1244.

Hartmann, A., and J. Heinze. 2003. Lay eggs, live longer: division of labor and life span in a clonal ant species. Evolution 57:2424-2429.

Heckathorn, D. D. 1996. The dynamics and dilemmas of collective action. American Sociological Review 61:250 277.

Heinze, J. 1998. Intercastes, intermorphs, and ergatoid queens: who is who in ant reproduction? Insectes Sociaux 45:113-124.

Hillesheim, E., N. Koeniger, and R. F. A. Moritz. 1989. Colony performance in honeybees (Apis mellifera capensis Esch) depends on the proportion of subordinate and dominant workers. Behavioral Ecology and Sociobiology 24:291-296.

Hurst, L. D., A. Atlan, and B. O. Bengtsson. 1996. Genetic conflicts. Quarterly Review of Biology 71:317-364.

Imperatriz-Fonseca, V. L. 1990. Swarming activity in Schwarziana quadripunctata (Apidae, Meliponinae). Pages 744-745 in G. K. Veeresh, B. Mallik, and C. A. Viraktamath, eds. Social insects and the environment. Oxford \& IBH, New Delhi.

Imperatriz-Fonseca, V. L., and A. Kleinert-Giovannini. 1989. Atividades de rainhas virgens em Plebeia (Schwarziana) quadripunctata (Apidae, Meliponinae). 
Res. do I Simpósio Latino-Americano sobre. Insetos Sociais Neotropicais (Rio Claro) 11.

Imperatriz-Fonseca, V. L., and R. Zucchi. 1995. Virgin queens in stingless bee (Apidae, Meliponinae) colonies: a review. Apidologie 26:231-244.

Keller, L. 1999. Levels of selection in evolution. Princeton University Press, Princeton, N.J.

Keller, L., and H. K. Reeve. 1994. Partitioning of reproduction in animal societies. Trends in Ecology \& Evolution 9:98-102.

Kerr, W. E. 1950. Genetic determination of castes in the genus Melipona. Genetics 35:143-152.

Kikuta, N., and K. Tsuji. 1999. Queen and worker policing in the monogynous and monandrous ant, Diacamma sp. Behavioral Ecology and Sociobiology 46:180-189.

Landolt, P. J., R. D. Akre, and A. Greene. 1977. Effects of colony division on Vespula atropilosa (Sladen) (Hymenoptera: Vespidae). Journal of the Kansas Entomological Society 50:135-147.

Leigh, E. G. 1991. Genes, bees and ecosystems: the evolution of a common interest among individuals. Trends in Ecology \& Evolution 6:257-262.

Maynard Smith, J. 1964. Group selection and kin selection. Nature 201:1145-1147.

- 1982. Evolution and the theory of games. Cambridge University Press, New York.

Michener, C. D., and D. J. Brothers. 1974. Were workers of eusocial Hymenoptera initially altruistic or oppressed? Proceedings of the National Academy of Sciences of the USA 71:671-674.

Michod, R. E. 1999. Darwinian dynamics: evolutionary transitions in fitness and individuality. Princeton University Press, Princeton, N.J.

Mock, D. W., and G. Parker. 1998. The evolution of sibling rivalry. Oxford University Press, Oxford.

Monnin, T., and C. Peeters. 1997. Cannibalism of subordinates' eggs in the monogynous queenless ant $\mathrm{Di}$ noponera quadriceps. Naturwissenschaften 84:499-502.

-1999. Dominance hierarchy and reproductive conflicts among subordinates in a monogynous queenless ant. Behavioral Ecology 10:323-332.

Monnin, T., and F. L. W. Ratnieks. 2001. Policing in queenless ponerine ants. Behavioral Ecology and Sociobiology 50:97-108.

Monnin, T., F. L. W. Ratnieks, G. R. Jones, and R. Beard. 2002. Pretender punishment induced by chemical signalling in a queenless ant. Nature 419:61-65.

Oldroyd, B. P., L. A. Halling, G. Good, W. Wattanachaiyingcharoen, A. B. Barron, P. Nanork, S. Wongsiri, et al. 2001. Worker policing and worker reproduction in Apis cerana. Behavioral Ecology and Sociobiology 50: 371-377.

Oster, G. F., and E. O. Wilson. 1978. Caste and ecology in the social insects. Princeton University Press, Princeton, N.J.

Ostrom, E. 1999. Governing the commons. Cambridge University Press, Cambridge.

Ostrom, E., J. Burger, C. B. Field, R. B. Norgaard, and D. Policansky. 1999. Revisiting the commons: local lessons, global challenges. Science 284:278-282.

Palmer, K. A., and B. P. Oldroyd. 2000. Evolution of multiple mating in the genus Apis. Apidologie 31:235-248.

Pamilo, P. 1991. Evolution of colony characteristics in social insects. I. Sex allocation. American Naturalist 137: 83-107.

Peters, J. M., D. C. Queller, V. L. Imperatriz-Fonseca, D. W. Roubik, and J. E. Strassmann. 1999. Mate number, kin selection and social conflicts in stingless bees and honeybees. Proceedings of the Royal Society of London B 266:379-384.

Pomeroy, N. 1979. Brood bionomics of Bombus ruderatus in New Zealand (Hymenoptera: Apidae). Canadian Entomologist 111:865-874.

Pomiankowski, A. 1999. Intragenomic conflict. Pages 121152 in L. Keller, ed. Levels of selection in evolution. Princeton University Press, Princeton, N.J.

Queller, D. C., and J. E. Strassmann. 1998. Kin selection and social insects. BioScience 48:165-175.

Ratnieks, F. L. W. 1988. Reproductive harmony via mutual policing by workers in eusocial Hymenoptera. American Naturalist 132:217-236.

. 1993. Egg-laying, egg-removal, and ovary development by workers in queenright honey-bee colonies. Behavioral Ecology and Sociobiology 32:191-198.

- 1995. Evidence for a queen-produced eggmarking pheromone and its use in worker policing in the honey-bee. Journal of Apicultural Research 34:3137 .

- 2000. Worker policing in the honey bee: basic facts and ideas. Insect Social Life 3:3-10.

- 2001. Heirs and spares: caste conflict and excess queen production in Melipona bees. Behavioral Ecology and Sociobiology 50:467-473.

Ratnieks, F. L. W., and H. K. Reeve. 1992. Conflict in single-queen hymenopteran societies: the structure of conflict and processes that reduce conflict in advanced eusocial species. Journal of Theoretical Biology 158:3365.

Ratnieks, F. L. W., and P. K. Visscher. 1989. Worker policing in the honeybee. Nature 342:796-797.

Reeve, H. K. 1991. Polistes. Pages 99-148 in K. G. Ross and R. W. Matthews, eds. The social biology of wasps. Cornell University Press, Ithaca, N.Y.

Reuter, M., and L. Keller. 2001. Sex ratio conflict and worker production in eusocial Hymenoptera. American Naturalist 158:166-177. 
Ribeiro, M. F., and D. A. Alves. 2001. Size variation in Schwarziana quadripunctata queens (Hymenoptera, Apidae, Meliponini). Revista de Etologia 3:59-65.

Ribeiro, M. F., V. L. Imperatriz-Fonseca, and P. D. Santos. 2003. Exceptional high queen production in the Brazilian stingless bee Plebeia remota. Studies on Neotropical Fauna and Environment 38:111-114.

Seeley, T. D. 1985. Honeybee ecology: a study of adaptation in social life. Monographs in Behavior and Ecology. Princeton University Press, Princeton, N.J.

Strassmann, J. E., B. W. Sullender, and D. C. Queller. 2002. Caste totipotency and conflict in a large-colony social insect. Proceedings of the Royal Society of London B 269:263-270.

Trivers, R. L. 1974. Parent-offspring conflict. American Zoologist 14:249-264.

Trivers, R. L., and H. Hare. 1976. Haplodiploidy and the evolution of the social insects. Science 191:249-263.

van Honk, C., and P. Hogeweg. 1981. The ontogeny of the social structure in a captive Bombus terrestris colony. Behavioral Ecology and Sociobiology 9:111-119.

Visscher, P. K. 1989. A quantitative study of worker reproduction in honeybee colonies. Behavioral Ecology and Sociobiology 25:247-254.

. 1996. Reproductive conflict in honey bees: a stalemate of worker egg-laying and policing. Behavioral Ecology and Sociobiology 39:237-244.

Ward, P. S. 1983. Genetic relatedness and colony organization in a species complex of ponerine ants. I. Phenotypic and genotypic composition of colonies. Behavioral Ecology and Sociobiology 12:285-299.

Wenseleers, T., and F. L. W. Ratnieks. 2004. Tragedy of the commons in Melipona bees. Proceedings of the Royal Society of London B 271(suppl.):310-312.

Wenseleers, T., F. L. W. Ratnieks, and J. Billen. 2003. Caste fate conflict in swarm-founding social Hymenoptera: an inclusive fitness analysis. Journal of Evolutionary Biology 16:647-658.

Wenseleers, T., A. G. Hart, F. L. W. Ratnieks, and J. J. G. Quezada-Euan. 2004. Queen execution and caste conflict in the stingless bee Melipona beecheii. Ethology 110: 725-736.

Wenseleers, T., A. Tofilski, and F. L. W. Ratnieks. 2005a. Queen and worker policing in the tree wasp Dolichovespula sylvestris. Behavioral Ecology and Sociobiology (in press).

Wenseleers, T., N. S. Badcock, K. Erven, A. Tofilski, F. S. Nascimento, A. G. Hart, T. A. Burke, M. E. Archer, and F. L. W. Ratnieks. 2005b. A test of worker policing theory in an advanced eusopcial wasp, Vespula rufa. Evolution (in press).

Wenseleers, T., F. L. W. Ratnieks, M. F. Ribeiro, D. A. Alves, and V.-L. Imperatriz-Fonseca. 2005c. Working-class royalty: bees beat the caste system. Biology Letters (in press).

Wheeler, D. E. 1986. Developmental and physiological determinants of caste in social Hymenoptera: evolutionary implications. American Naturalist 128:13-34.

Wilson, E. O. 1971 The insect societies. Harvard University Press, Cambridge, Mass.

Winston, M. L. 1987. The biology of the honey bee. Harvard University Press, Cambridge, Mass.

Associate Editor: Eldridge S. Adams 